\title{
PAKISTAN IS AT POLITICAL AND ECONOMIC RISK AFTER TALIBAN TAKEOVER OF AFGHANISTAN
}

\author{
Armaghan Farid \\ PhD Scholar, Department of Political Science, \\ University of the Punjab, Lahore, Punjab. Pakistan \\ armaghannfaridd@gmail.com
}

Shaharyar Ahmed

Lecturer, Department of Pakistan Study, Govt College for Boys Satellite Town, Gujranwala, Punjab, Pakistan

\begin{abstract}
The change in Afghanistan always affected the whole region of Central Asia and especially Pakistan because both countries have a unique relationship. They have religious, cultural, and ethnic connections. They were described as inseparable brothers by former Afghan leaders like Hamid Karzai. So as far as peace and security of the region is concerned stability among both sides of borders is important. After 21 years of insurgency the recent takeover of Afghanistan by Taliban, who are known as Pashtun Islamic fundamentalists, has brought significant changes in the region. This research is focused on the political and economic impacts of Pakistan's Afghan Policy on Pakistan after Taliban takeover of Kabul. It is also looking into the strength and weaknesses, irritants and multipliers of PakAfghan policy to make suggestions for improvement. The primary purpose of this study is to identify the ways through which Pakistan can overcome its Political and economic crises after Taliban in Afghanistan and to give a new direction to Pak-Afghan relations for peace and Stability in the region. The article also tries to analyze the international political stance on Current Pak-Afghan relations and is divided into four parts, 1) Pakistan's Afghan policy after August 15, 2021(Taliban take over) 2). International Political Stance on Pakistan's Perspective of Taliban's rule in Afghanistan 3). Impact of Taliban rule on Pakistan's economy 4). Way out.... Suggestions and recommendations
\end{abstract}

Nida Shabbir

PhD Scholar, Department of Political Science, University of the Punjab, Lahore, Punjab, Pakistan

n_shabbir87@yahoo.com

Keywords: Taliban, Policy, Economy, Afghanistan, International Politics, Institutions, Governance, militancy.

\section{INTRODUCTION}

Taliban are mostly local Pashtun, Islamic fundamental group that returned to power in Afghanistan after 21 years of insurgency. When they emerge in 1990's they were fully supported by Afghan population because of corrupt government and foreign invasion. Their regime was collapsed by US-led invasion in 2001. They fight back, regrouped themselves and take control of major cities of Afghanistan in August 2021. International actions against the Taliban regime in both eras of 1990's and 2021 has not only had regional, Political and Security impact, but has also changed international approaches towards South Asia in general and Pakistan in particular. Pakistan is the important and permanent neighbor of Afghanistan, having common religious, social and cultural values and is one of the first countries to welcome Taliban return to power in August 2021 with the statement of Prime Minister Imran Khan said that Afghans had broken the shackles of slavery (Chaudry, 2021).

Afghanistan was in constant war like situation from last 20 years. One cannot give exact numbers of lost lives, but an estimated loss of Afghan Security forces by Brown University Research is about 69,000. 20,000 US soldiers were injured, and 3500 coalition soldiers died. With reference to United Nations report, Afghanistan is having the third largest displaced population in the world, about 
5 million people fled from Afghanistan since 2012 and were not able to come back to their country. The US presence in Afghanistan was a constant pressure on US economy as well, according to the research of Brown University, the total military and reconstruction funds are 978 \$ bn till 2020 (Team, 2021). The total US military presence can be seen in the following graph (Team, 2021).

\section{US troop levels in Afghanistan}

\section{$2002-2020$}

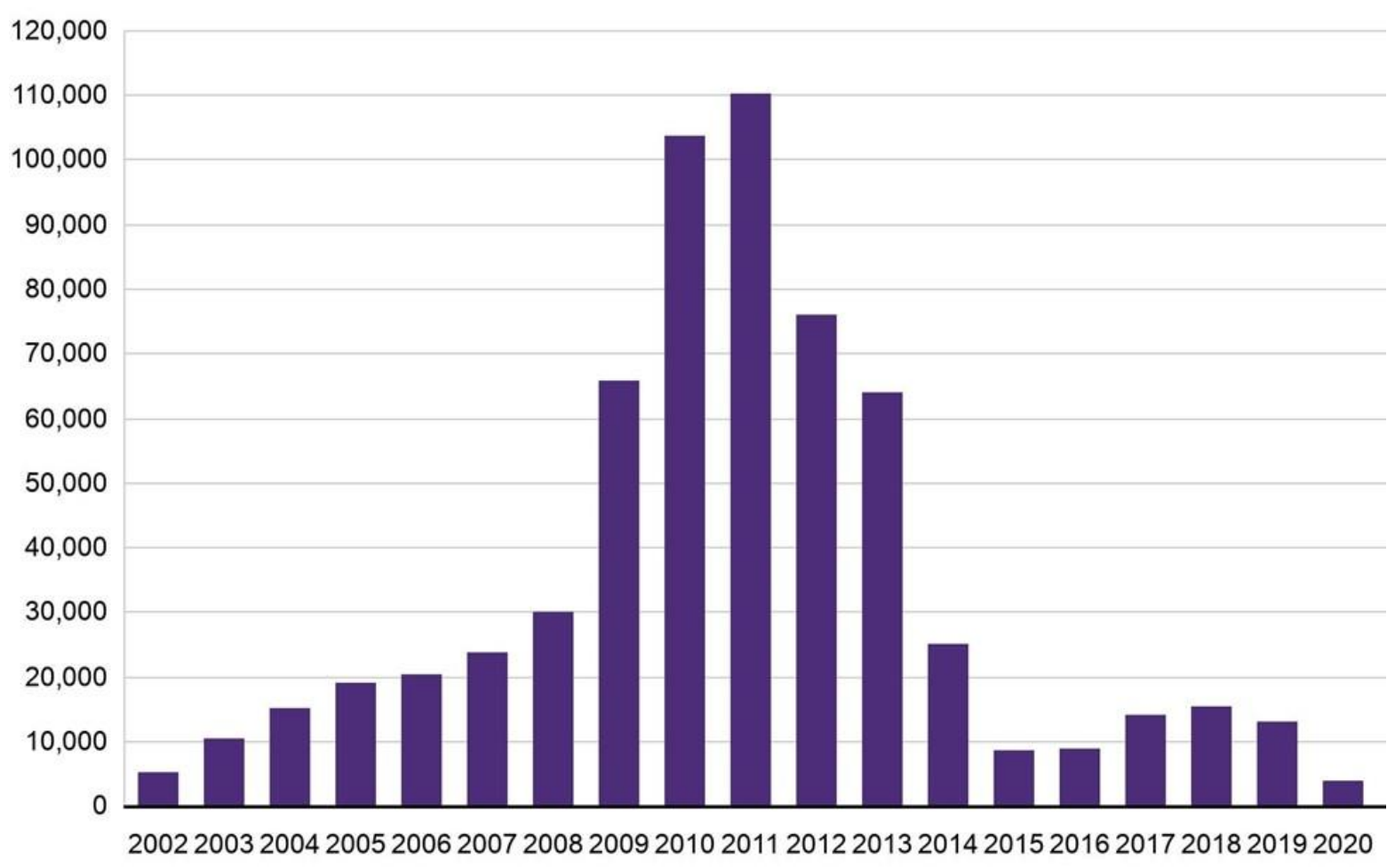

2020 figure as of December

Source: Special Inspector General for Afghanistan Reconstruction (SIGAR), Congressional Research $\quad$ BBC Service

As far as Pakistan is concerned in the past it was pursuing an interventionist Afghan policy in order to counter Indian influence in Afghanistan and to ensure friendly relations with Kabul. Unfortunately, that policy badly failed because it's both strategic goals are far away from reality. IndiaAfghan relations have become warmer as they were 40 years ago whereas in comparison to that, there is an environment of huge distrust between Pakistan and Afghanistan. Their Pro Taliban policy leads them towards international isolation. Within the country it caused domestic terrorism, which costs Pakistan over 60,000 lives and 100 billion dollars of economic losses. To pursue this security centric Afghan policy Pakistan badly compromised on its geo-economic interests, increased trade with Afghanistan, access to resource-rich Central Asia and repatriation of Afghan refugees (Kakar, 2021). Now the current situation of Afghanistan provides an opportunity to Pakistan to resolve all its previous issues and start afresh and try to gain trust of young Afghan generation who have never experienced peace because peace in Afghanistan will lead towards peace in Pakistan, especially in Baluchistan (Kakar, 2021).

The current situation in Afghanistan i-e the withdrawal of US forces and Taliban takeover of Kabul is perceived as a positive development by the political and military circles of Pakistan. They believe that with Taliban Power in Afghanistan their western borders will be secured because India will be out of the scene. This confidence on Taliban strengthened because they never retaliated with violence although Pakistan was giving support to the US military operation which dismantled Taliban's government in 2001. The visit of Pakistani ISI Chief General Faiz Hameed on Sep 4, 2021 also started a lot of speculation about their involvement in Afghanistan at International arena. There is no doubt that Pakistan's government is trying hard to engage international community with Taliban, Prime Minister 
Imran Khan while talking to International Community in UN General Assembly on Sep 24, 2021, urged them to support Afghanistan and help them with humanitarian aid.

Pakistan is also very careful and will not go for quick response of recognizing Taliban government alone as they did in 1990's because, it is the fact that Pakistan will not get that full command and authority over Taliban as it was having in the past. It has been clarified to the parliamentarians by the military commanders in National security meeting on August 24, 2021, that Taliban will not obey or listen Pakistan as they did in the past. Today Pakistan's support to Taliban doesn't mean that they are fully comfortable with their Kabul takeover, they suffered a lot because of terrorist attacks over Afghanistan border. Their interest lies in Taliban government because of their strict and firm stance on Al-Qaeda and ISIS and do not want to leave Afghanistan as an ungoverned space.

The other alarm is of refugees, Pakistan's ravaged economy cannot afford to host more Afghan refugees as they are already hosting 3 million of them. Moazzam Ahmed Khan, Pakistan's High Commissioner to UK while talking to BBC stated that, Pakistan do not have the capacity to host more refugees that is why we are requesting again and again to work on the possibility of avoiding Civil war situation in Afghanistan (Miller, 2021).

\section{POLITICAL CONSEQUENCES FOR PAKISTAN}

Pakistan is supporting Taliban's with the goal to stop Pashtun Nationalism and counter India with the help of friendly government in Afghanistan but it is quite risky as well because it can be a great security risk for Pakistan as they have close relations with Pakistani active Tehrik-e-Taliban (TTP) which is based on small Pashtun militant groups usually operate along Pakistan-Afghan border and their purpose is to have an independent Pashtunistan. To attain this purpose they are not only trying to wage a war in Pakistan but also killed thousands of Pakistani civilians. Definitely the success of Taliban encouraged TTP and they will try to replicate Afghani Taliban model of government in Pakistan especially in Pashtun areas. According to the short term political risk index score of Fitch solutions Pakistan is at 42.7 out of 100 .

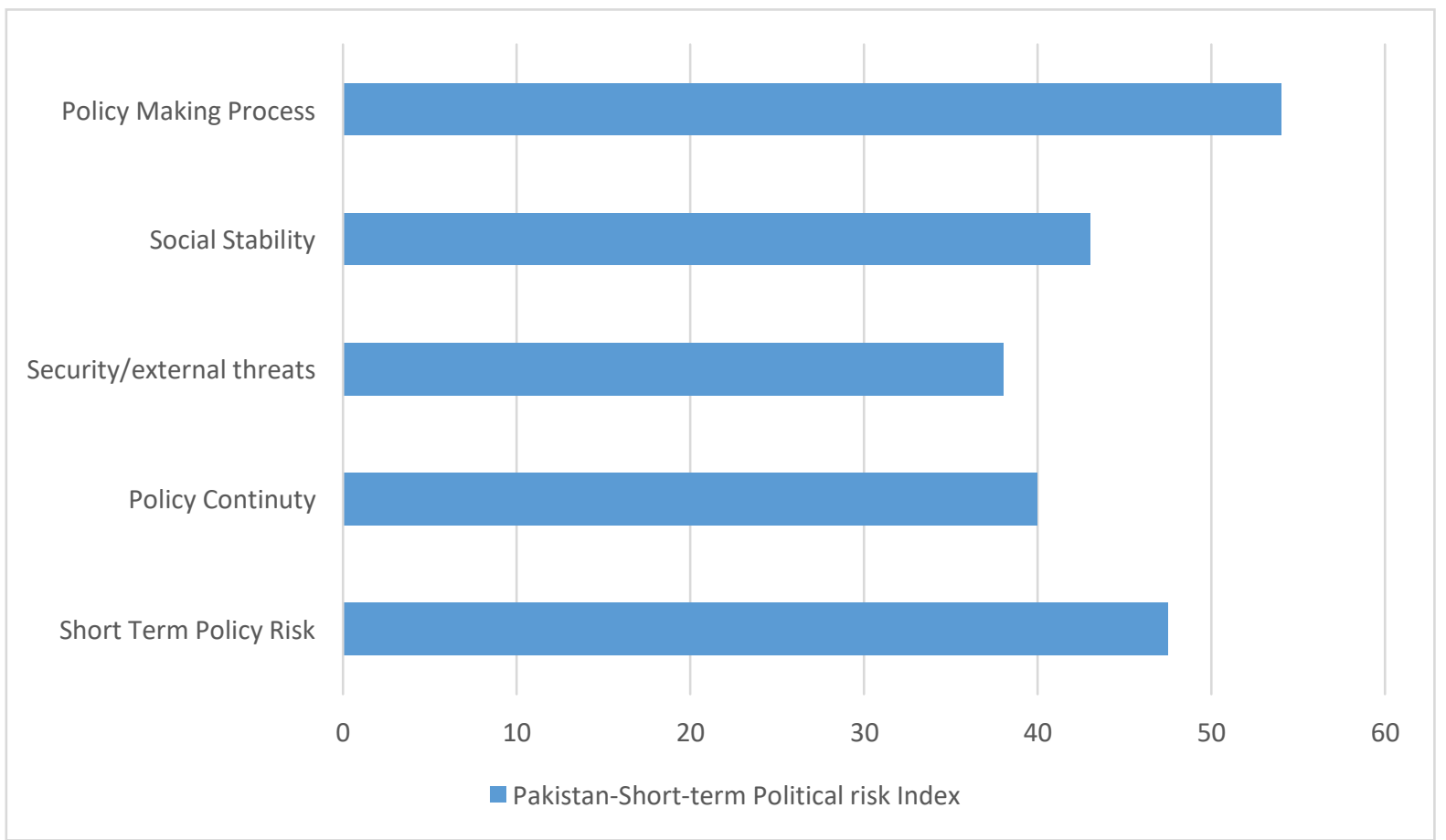

Source: Fitch Solutions (Fitch Solution, 2021)

This situation is not as ideal for Pakistan as it looks like; the warnings are already given to Pakistani lawmakers by military head General Bajwa that these groups are two faces of same picture. Madiha Afzal a David M. Rubenstein fellow in the foreign policy program at Brookings institution while talking to CNBC, stated that links of Afghan Taliban with Pakistani Taliban are both operational and ideological, recently they released some TTP prisoners from Afghanistan prisoner's jail which can 
pose a serious threat to Pakistan Security in future. She further added that Pakistan is trying hard to maintain its international image of non-supporting terrorism but their current close proximity with Taliban can be serious problems to their international repute (Afzal, 2021).

Taliban are in talks with India and almost agreed on Indian stance over Kashmir that it's their internal and bilateral issue and they will not take part in Kashmiri freedom fight although Pakistan is backing Taliban rule to counter India. Now the question here is that Pakistan's good and bad Taliban strategy is really successful or not? And by looking into the situation one can easily understand that as Pakistan used them, Taliban also used Pakistan for their gains. There explanation of good and bad is that good Pakistan supported them against US-led forces and helped them to get some of western resources whereas bad Pakistan is which think or believe that Taliban have to follow or respond to geopolitical and ideological commitments (Shahid, 2021).

Pakistan sacrificed the lives of 80,000 of its citizens for Talibanization in Afghanistan, which is termed as collateral damage by Pakistan's military. Prime Minister Khan by giving the statement in favor of Taliban promoted the US stance of reducing its financial aid for Pakistan. Their support to Taliban is not only giving political setbacks but also creating economic issues. As they have links with TTP which is responsible of killing thousands of innocent Pakistani's in terror attacks, so it is strongly believed that Taliban rule will create tremendous security risks at Pak-Afghan border and TTP will be encouraged with the success of Afghan Taliban and they will try to replicate their rule in Pakistan Pashtun areas.

No doubt that Taliban presence in Afghanistan is giving a geo political edge to Pakistan over India in Central Asia. A strong, peaceful, and stable Afghanistan will increase Pakistan's Strategic partnership with Central Asian states but for this Taliban's need to have a political consensus with all Afghan stakeholders. Without any Political settlement, peace cannot be restored and their capability of developing themselves into an economic and energy corridor which link South Asia with Central Asia will never be recognized.

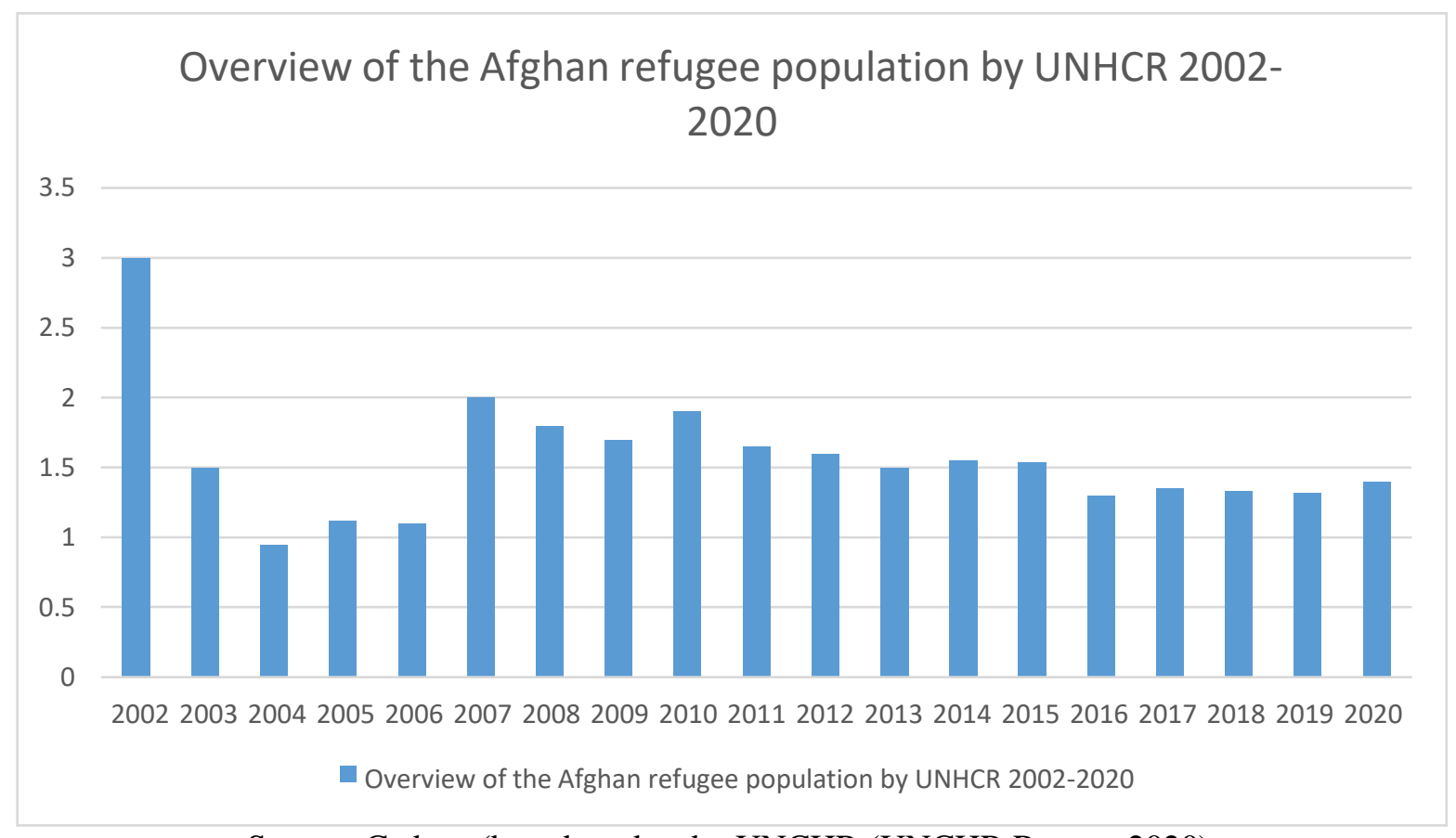

Source: Cedoca (based on data by UNCHR (UNCHR Report, 2020)

Another great concern is of refugees, if there started a civil war in Afghanistan, Pakistan will have to deal with another influx of refugees. As Pakistan is already hosting three million Afghan refugees, another mass of people will be a major concern for Pakistan's economy. In addition to that this support can endanger Pakistan's relations with China because it can become a sanctuary for Muslim separatists including disaffected Uyghurs from Xinjiang. 
Pakistan support to Taliban's almost ruined its relations with US. President Joe Biden not even call Prime Minister Khan after holding his presidential office. In a policy exchange seminar, Lt Gen Mc Master, one of the former US National Security advisor suggested that US should stop treating Pakistan as a Pariah State if it refused to support Taliban, Pakistan is not a partner anymore, they are behaving like enemy by training and organizing extremist groups and using them as an arm for their foreign policy (Afzal, 2021). In a congressional hearing US secretary of state Antony Blinken said that US should examine the role which Pakistan was playing from last 20 years and what they will play in the future. A bill is proposed by republican lawmakers in senate about sanctioning of new Taliban government in Afghanistan and those who are supporting them. It also demands for a valuation of support to Taliban by state and non-state actors including Pakistan from 2001 to 2020. This situation is alarming for Pakistan, and to counter this Pakistan is arguing that US is trying to put the blame of his failure in war over Pakistan and ignoring their own support to Taliban. In comparison to US, other Western powers are trying to approach Pakistan because they believe that Pakistan can persuade Taliban in one way or another. The foreign Ministers of Germany, Britain and Italy visited Pakistan to contain Pakistan's further closeness to China (Afzal, 2021).

The British High Commissioner, Christian Turner, while talking to a seminar in Islamabad, said that, stable Afghanistan is our shared goal, we are talking to the Taliban's and we would like to work with Pakistan for humanitarian assistance in Afghanistan. Russian President Viladimar Puttin, discussed the evolving Afghan situation with Prime Minister Khan on a phone call, and this conversation is followed by the successive meetings of foreign ministers and intelligence heads (Latif, 2021). The two countries decided to remain in close contact for bilateral cooperation. Intelligence heads of eight countries came to Pakistan in September, 2021 to discuss the afghan situation. At SAARC meeting, Pakistan was alone to ask for Taliban to sit in the meeting as afghan representative whereas other countries are not willing to do so and the meeting was cancelled.

There is a mix response for Pakistan role in Afghanistan at international platform. Mostly governments are skeptical about Pakistan behavior they thought that key to control Afghanistan is Pakistan although Pakistan denied the fact for several times but its constant appeal for Afghan international recognition is spoiling its international political image.

\section{ECONOMIC CONSEQUENCES}

In 2002 after the renewal of bilateral relations, a joint economic commission was setup which enhanced the possibility of economic cooperation between Pakistan and Afghanistan. A lot of agreements were signed in different areas including, for the opening of banks, promotion of investment, and for the construction of railway lines for trade routes. Pakistan also signed an agreement for the construction of gas pipeline on 25 December 2002, with Afghanistan and Turkmenistan. Their bilateral trade increased with years, it was about 435 million dollars in 2002 and till 2007 it increased to 1.5 billion dollars. Pakistan was trying to increase it till 2 billion dollars and in 2011 it reached to its targeted level. Pakistan was continuously trying to improve bilateral trade, for which they started working for the improvement of Afghan State institutions and by the end of 2009 different projects in health, communication and education sector with the cost of 87.02 million dollars were completed. Although Afghan transit trade destabilize Pakistan's manufacturing industry and supported the rise of powerful black economy which got a boom in 2002 and rise to 1300 billion rupees. The continuous smuggling of foreign goods from Afghanistan also affected the lifestyle of Pakistani's by adding western culture in it. It divided Pakistani society into modern and traditional liberal and conservative, rich and poor, rural and urban (Sultana, 2011). This all support of Pakistan goes in vain when previous Ashraf Ghani government under the Indian influence started preferring Iranian ports which dropped the flow of imported goods to Afghanistan through Pakistani Ports to $80 \%$. There bilateral trade also declined from 2.8 billion to 1.8 billion dollars.

Now in the current scenario of August 15, 2021, when Taliban took the control of Kabul, Pakistan is hoping for efficient bilateral economic relations with Afghanistan. There is a hope that under Taliban strict security Pakistan will be able to increase and strengthen its trade with Central Asia. They further believe that Taliban rule will help in providing security to TAPI i-e Turkmenistan- AfghanistanPakistan and India gas pipeline, which distribute gas from Turkmenistan to Pakistan, India and Afghanistan. But it will put negative impacts on Pakistan economy as well, firstly because of the decline 
in Foreign Direct Investment Pakistan economy is already shrinking. One of the Country's top newspaper, Dawn stated that Pakistan's economic managers are worried on the continuous decrease of FDI flows, which fell under 39 percent in July. According to the last four years data of State bank inward flow of FDI is falling whereas the outward flow surged over time. It further reported that FDI stocks have declined from 41.9 billion dollars to 5.6 billion dollars from 2016 to 2020. It was expected that Afghanistan situation will further shrink the FDI flow and it happened just after the collapse of Kabul. (Times, 2021) The decline in the value of Pakistani international Sukuh bond shows the drop of confidence of International investors on its economy. If the uncertainty and instability will linger on in Afghanistan it can further reduce Pakistan's export revenues.

Secondly, Pakistan was one of the leading recipients of Afghan refugees, which created problems in its own domestic economy. In 2016, to release its economic burden, Pakistan started a campaign to send back afghan refugees. But again in 2021 after US withdrawal Pakistan announced that they will support afghan refugees and settle them in special camps. Now the economic conditions are like in fiscal year 2021/22, Pakistan's budget deficit is at 6.3\% of GDP and current account deficit is between $2.0 \%$ and $3.0 \%$ of GDP, this constant increase in budget deficit generate a lot of macroeconomic stability risks which Pakistan has to consider. Now accommodating more afghan refugees need more financial assistance and will increase imports as well. According to the media reports till the end of august 20,000 refugees have crossed the border on daily basis and for their proper rehabilitation Pakistan government needed 2.2 US billion dollars (Fitch Solutions, 2021).

There is a complex history of relationships between Pakistan and US. The war on terror in Afghanistan forced US to rely on Pakistan air space and intelligence services for its counter- terrorism operations. But they are always doubtful and suspicious about Pakistan's efforts and believe that Pakistan is providing financial assistance to Taliban. In the recent interview of Prime Minister Khan, he clearly opposed the idea of allowing to operate US-military base in Pakistan. As Pakistan is heavily relying on US aid so this bold statement can affect the amount of aid which US is giving to Pakistan. They already cut down half of the aid in respective years of 2011, 2017, and 2021.

Lastly a matter of regional and global connectivity, for which Pakistan is strongly pursuing $\mathrm{CPEC}$ and labeled it as a game changer. CPEC, China-Pakistan Economic Corridor is of 64 billion dollar rupees and will connect the northwestern Province of Xinxiang, China to Gwadar in Baluchistan with the network of roads, railways and pipelines. Unfortunately Pakistan, because of its heterogeneous militant society failed to assure China about the security of the project.

China's interest in the region is increasing day by day, and there is a possibility of Afghanistan involvement in Belt and Road Initiative (BRI) as well. They are even more active in providing aid to Afghanistan. No doubt that their rational approach toward Afghanistan come together with Pakistan's regional stance but China's investment can decline due to TTP Violent attacks against Chinese, like death of nine Chinese engineers in a bus bomb blast who were working on Dasu hydro power project which postponed the important joint committee meeting on Road and Belt Initiative. If these types of incidents will continue than China will definitely reduce its involvement in Pakistan. As China is Pakistan's biggest contributor of FDI providing 41.0\% of total FDI of fiscal year 2020/21, so their less involvement will badly affect Pakistan's economic prospect. But Taliban's can convince China that they can be the better protectors, and they already agreed to support China against Uyghur separatists. Their (Afghanistan) mineral wealth is about 1 trillion dollars which they can offer them, and if they become the more convincing guarantor of the projects affiliated with CPEC than their alliance with China would be stronger and they will try to extend their influence across Pak-Afghan border, which they never consider as a border (Fitch Solutions, 2021).

\section{RECOMMENDATIONS}

The emergence of Taliban in Afghanistan as a ruling government fulfills some of Pakistan's strategic interests. The last ruling elite of Afghanistan was backing India to strategically implant itself in the country. That Indian presence supported Baloch insurgents and TTP that evolved terrorist activities in Pakistan. Now Pakistan believe that this new situation will end Indian structural presence and will not allow India to use Afghan soil against Pakistan. This will give a security relief to Pakistan as it only has to focus one war front. 
Afghanistan's Natural resources and its wrecked infrastructure is a center of interest for China whereas Central Asian states will try to use Afghanistan as an export route for their natural gas and Oil to Pakistan, India and to the open sea of Indian Ocean. Now if Afghanistan controls its internal conflict and establishes itself as a stable and functioning state, it can transform Pakistan economically and politically but on the other hand if it fall back to its long history of war and conflict or if it became an extremist ideological state than it will be a serious threat or embracement for Pakistan. In first scenario Pakistan can play a role of bridge between Afghanistan and the outside world but in the second one they have to pay high international and domestic price of long standing Taliban support. The best solution in this scenario is to wait for International recognition of Afghanistan instead of recognizing it alone like Pakistan did before in 1990's.

The release of prisoners including senior TTP leaders is a matter of great concern for Pakistan because TTP is posing a serious threat to Pakistan especially in north western province of KPK. Although Afghan Taliban has assured Pakistan that they will not allow anyone to use their soil against any other country but their reluctancy on taking clear position on TTP and concerns on Pak-Afghan border fencing is quite distressing for Pakistan. As there government is new and not recognized by International community so they are politically isolated and need Pakistan support which can give Pakistan more leverage on TTP issue but still as they are not reliable Pakistan need to keep its eyes open as Hilary Clinton once said that you cannot keep snakes on your back yard and expect them to bite your neighbors only, they will come to bite you one day as well.

Pakistan should join hands with major and regional powers like China, Russia, Iran, and Central Asian states to stop militants, transnational terrorist's threats like ISIS, and drugs/arms trafficking from Afghanistan. Pakistan should stress all major powers to support Afghanistan rebuilding and restructuring to create pull factor for the return of 4 million Afghan refugees stationed in Pakistan. Because the current Taliban power is predicting more refugee flow and Pakistan already struggling economy is not in a position to bear that flow.

Taliban are mostly ethnic Pashtuns, their strong governmental hold in Afghanistan can provoke Pashtun Nationalism on Pakistan's western border. To counter that situation effective border management is needed because more bilateral trade, people to people exchange, allowing Afghan students to study in Pakistani educational institutes, providing medical treatment will promote their confidence on Pakistan and will be helpful in reducing hatred.

\section{CONCLUSION}

Afghanistan is heart of Asia and can also be characterized as economic roundabout. The new Taliban government can use the current situation in their favor by adopting soft and peaceful policy which will help them to convert Afghanistan into a hub of economical connectivity for the three sub regions of Asia. On Pakistan side many politicians including Prime Minister Imran Khan supported Taliban takeover of Kabul without looking into the problems which Taliban presence can create for Pakistan. No doubt that Pakistan has got a geo-political supremacy over India and Central Asia region with Taliban rule in Afghanistan. But it is also a fact that their presence can also present security and economic risks for Pakistan. Their strict policies can cause a heavy flow of refugees towards Pakistan, it can also cause security risks by supporting TTP, and their non-alliance policies can create hurdles in Pakistan's access to Central Asia. US support to Pakistan economy is under consideration after their withdrawal from Afghanistan because of their doubts towards Pakistan which left no other option for them than to rely and deepen its already close ties with China. Now China reliance on Afghanistan Natural resources can put Pakistan already deteriorating economy into trouble. International community is still not clear about its descion regarding the acceptance of Taliban government Now in this whole scenario Pakistan's role in Afghanistan reconciliation is quite critical, they can play a role of facilitator but it would be a huge mistake if they become party to any ethnic divide in Afghanistan. The current situation in Afghanistan leads Pakistan toward tough choices. At one side Taliban power will enhance Pakistan influence in Afghanistan and on the other side strong, powerful and independent Taliban are against Pakistan's interest. Although Biden's descion of withdrawal is a sigh of relief for US and coalition forces but it started an era of new struggle for Pakistan. 


\section{REFERENCES}

Afzal, M. (2021, August 6). An uneasy limbo for US-Pakistan relations amidst the withdrawal from Afghanistan. Retrieved from Brookings: google chrome

Afzal, M. (2021, October 13). Post Afghanistan, US-Pakistan relations stand on the edge of a precipice. Retrieved from Brookings: https://www.brookings.edu/blog/order-fromchaos/2021/10/13/post-afghanistan-us-pakistan-relations-stand-on-the-edge-of-aprecipice/

Chaudry, S. R. (2021, September 21). Pakistan should worry about consequences of Taliban's success in Afghanistan, former ambassador says. Retrieved from CNBC: https://www.cnbc.com/2021/09/14/afghanistan-pakistans-strategy-in-kabul-and-whathappens-next.html

Gul, A. (2021, December 14). Britain, Pakistan Urge Collective Response to Afghan

Humanitarian Crisis. Retrieved from south \& central asia: https://www.voanews.com/a/britain-pakistan-urge-collective-response-to-afghanhumanitarian-crisis/6354460.html

Kakar, R. (2021, july 24). Pakistan's Afghan policy. Retrieved from The News: https://www.thenews.com.pk/print/867484-pakistan-s-afghan-policy

Latif, A. (2021, September 14). Russian president discusses Afghanistan situation with Pakistani premier. Retrieved from Politics, World, Asia-Pacific: https://www.aa.com.tr/en/asia-pacific/russian-president-discusses-afghanistansituation-with-pakistani-premier/2364909

Manjari Chatterjee Miller. (2021, August 25). Pakistan's Support for the Taliban: What to Know: Retrieved from https://www.cfr.org/article/pakistans-support-taliban-whatknow

News, B. (2021, august 30). Taliban are back - what next for Afghanistan? Retrieved from BBC news: https://www.bbc.com/news/world-asia-49192495

Report, C. O. (2020, May). Pakistan Situation of Afghan refugees. Retrieved from EASO: https://easo.europa.eu/sites/default/files/publications/easo-coi-report-pakistansituation-afghan-refugees.pdf

Shahid, K. K. (2021, August 19). How the Taliban Used Pakistan. Retrieved from The diplomat: https://thediplomat.com/2021/08/how-the-taliban-used-pakistan/

Solutions, F. (2021, September 23). Pakistan Faces Increased Economic And Political Risks From Taliban's Takeover Of Afghanistan. Retrieved from Fitch Solutions: https://www.fitchsolutions.com/country-risk/pakistan-faces-increased-economic-andpolitical-risks-talibans-takeover-afghanistan-23-09-2021?fSWeb

Sultana, R. (2011). Pakistan-Afghan Economic Relations: Issues and Prospects. Pakistan Horizon, 64(1), 21-37.

Team, R. C. (2021, September 3). Afghanistan: What has the conflict cost the US and its allies? Retrieved from BBC News: https://www.bbc.com/news/world-47391821

Times, T. E. (2021, August 26). Afghanistan crisis may 'shrink' Pakistan's economy. Retrieved from The economic times news. 